\title{
Reproductive and productive performances of Santa Inês ewes submitted to breeding in different periods of the Amazonian humid tropical climate
}

\author{
Felipe Nogueira Soares ${ }^{1}$ - Maria Emilia Franco Oliveira ${ }^{2}$. \\ Luciana Cristina Padilha-Nakaghi ${ }^{2}$ - Luís Guilherme de Oliveira ${ }^{3}$. \\ Marcus Antônio Rossi Feliciano ${ }^{2}$ Felipe Brener Bezerra de Oliveira ${ }^{1}$. \\ Pedro Paulo Maia Teixeira ${ }^{2}$ - Wilter Ricardo Russiano Vicente ${ }^{2}$. Cristian Faturi ${ }^{1}$. \\ Luiz Fernando de Souza Rodrigues ${ }^{1}$
}

Received: 6 October 2014 / Accepted: 13 July 2015 /Published online: 30 July 2015

(C) Springer Science+Business Media Dordrecht 2015

\begin{abstract}
The objective of this study was to evaluate the reproductive and productive performance of Santa Inês ewes bred at different times of the year in humid tropical climate. One hundred and forty-eight Santa Inês ewes were grouped according to the time of the year of their breeding season (i.e., mating period) (dry/wet, wet, wet/dry, and dry season). The service type was natural mating and the ewes and rams were kept together every night for 45 days. Reproductive efficiency was assessed by service, pregnancy, lambing, prolificacy, twinning, pregnancy loss, weaning, and lamb mortality rates. Ewes were weighed at the beginning and at the end of the breeding season and before and after parturition, and sequential weighing of the lambs was performed (at birth, 15, 30, 60, and 90 days). Reproductive efficiency index (number of lambs weaned/total of served ewes) and productive efficiency (kg of weaned lamb/kg of served or lambed ewes) were calculated. All ewes expressed estrus early in the breeding season; however, a higher percentage (53.5 and $7.1 \%$ at 30 and 45 days, respectively) of ewes returned to estrus during the wet/dry period. The lower rates $(13.9 \%)$ of return to estrus at 30 days
\end{abstract}

Maria Emilia Franco Oliveira

m_emiliafraoli@yahoo.com.br

Institute of Animal Health and Production, Federal Rural University of Amazon, Belém, Pará, Brazil

2 Department of Preventive Veterinary Medicine and Animal Reproduction, College of Agricultural and Veterinary Sciences, São Paulo State University, Jaboticabal, São Paulo, Brazil

3 Department of Clinical and Veterinary Surgery, College of Agricultural and Veterinary Sciences, São Paulo State University, Jaboticabal, São Paulo, Brazil were during the wet season $(P<0.05)$. There were no $(P>0.05)$ effects of breeding seasons on the remaining reproductive rates. Ewes that lambed during the wet/dry transition period weighted less, before $(40.5 \pm 2.5 \mathrm{~kg})$ and after $(38.6 \pm$ $1.6 \mathrm{~kg})$ parturition, than those of other groups $(P<0.05)$. Lamb weight at birth did not vary between groups, however, weight at weaning was higher $(15.6 \pm 2.1 \mathrm{~kg})$ in lambs born during the wet season $(P<0.05)$. The reproductive efficiency index was lower (0.66) when the breeding season took place during the dry/wet period $(P<0.05)$. Productive rates were significantly higher $(0.29$ and 0.33 for $\mathrm{kg}$ of weaned lamb $/ \mathrm{kg}$ of served and lambed ewes, respectively; $P<0.05$ ) in ewes served in the dry season. The reproductive performance of Santa Inês ewes was not significantly influenced by the period of the year in which the breeding seasons took place, allowing for four breeding seasons a year in the Amazon region. Variations between periods in return to estrus rates, weight of ewes close to parturition and lamb weight at weaning indicate that climate changes can also affect reproductive rates.

Keywords Sheep · Weather condition · Production · Reproduction

\section{Introduction}

In recent years, the North of Brazil has been the region with the greatest growth in sheep numbers in the country, with approximately $7 \%$ increase in total flock numbers from 2010 to 2011 (IBGE 2011).

The Amazonian climate is characterized by intense rainfall associated with high temperatures and humidity throughout 
the year, and this combination of factors can cause intense discomfort to animals (Costa et al. 2010). Small ruminants raised in tropical climate are not significantly influenced by the photoperiod; however, it is known that other environmental factors such as heat stress and the quality and availability of feed can directly interfere with animal reproduction (Simplício 2008). Thus, climatic factors are closely related to animal productive and reproductive performance, which may vary according to the region in which the animals are raised (Oliveira et al. 2013a).

Animal adaptation to its breeding environment is essential for the success of any livestock enterprise, thus making the establishment of husbandry and genotype selection strategies essential tools in this process (as reviewed by Façanha et al. 2013). These authors have also reviewed the importance of evaluating the indicators of reproductive function such as fertility, prolificacy, reproductive behavior, body condition score, maternal ability, and survival rate of the offsprings in order to determine the adaptability of the genetic groups to their environment. It is important to point out that the influence of climatic factors on the production and reproduction of livestock has been a subject of great interest in recent years with research aiming to understand its particularities and thus improve animal production, as demonstrated by Moura et al. (2014), Oliveira et al. (2013a), and Silva et al. (2011).

The understanding of the climatic variables; their interaction with the sheep flocks; and the behavioral, physiological, and productive responses of the animals are of great importance in the tailoring of local production systems (Neiva et al. 2004). With this in mind, it is of uttermost importance to determine the climatic influence during the different periods of the year on the productive and reproductive efficiency of the sheep flocks. It is noteworthy that study of four breeding seasons throughout the year in the Amazon region has not been done yet. Thus, the aim of this study was to evaluate the reproductive and productive performance of Santa Inês ewes bred at various periods of the year under the tropical Amazonian climate.

\section{Material and methods}

The study was conducted during the different seasons of the year in a commercial farm in the North region of Brazil $\left(01^{\circ}\right.$ $07^{\prime} 44^{\prime \prime} \mathrm{S}$ and $47^{\circ} 37^{\prime} 12^{\prime \prime} \mathrm{W}$ ) which has a climate type Am according to Köppen's classification, being characterized by two well defined seasons, wet and dry, and two periods of transition, wet/dry and dry/wet. Climatic data (maximum, minimum, and average temperatures; relative humidity and rainfall) were recorded each month of experimental period (Table 1$)$. The temperature-humidity index (THI) was calculated according to Thom (1958); THI $=0.8 \times T+(H /$ $100) \times(T-14.4)+46.4$, in which $T=$ environmental temperature $\left({ }^{\circ} \mathrm{C}\right) ; H=$ relative humidity; average and maximum THI were considered. THI values were used to classify the thermal discomfort levels of the animals as follows: absence of stress (THI<70); alert (between 70 and 72); critical (between 73 and 78); dangerous (between 79 and 82); and emergency (superior to 83; Hahn 1985).

One hundred and forty-eight Santa Inês ewes with average live weight of $40.0 \pm 4.9 \mathrm{~kg}$, body condition score between 2.5 and 3 (1-5, Gunn et al. 1984) and of 2-3 years of age were used in this study. The ewes were kept in a semi-intensive system, in which they were allowed to graze in Brachiaria humidicola, Brachiaria brizantha, and Panicum maximum cv. Massai (in the morning and, at the end of the day, were penned $\left(1.5 \mathrm{~m}^{2} /\right.$ ewe) and fed ( $1 \%$ of live weight, adjusted fortnightly) of cut pasture (Pennisetum purpureum, Saccharum officinarum L., and Pueraria phaseoloides) and $200 \mathrm{~g} / \mathrm{head} /$ day of $18 \%$ crude protein feed (Table 2). Water and mineral salt were provided ad libitum.

Ewes were randomly divided into four groups (Fig. 1) according to the time of the year of their breeding season (i.e., mating period). The dry/wet transition period group $(n=30)$ bred during the transition from late dry season to early wet season (January and February) and lambed during the wet/dry transition period (June and July). The wet season group ( $n=$ 43) bred during the wet season (April and May) and lambed during the dry season (September and October). The wet/dry transition period group $(n=28)$ bred during the transition from late wet season to early dry season (July and August) and lambed during the dry/wet transition period (December and January). The dry season group $(n=47)$ bred during the dry season (October and November) and lambed during the wet season (March and April).

Each breeding season lasted for 45 days and four rams, previously tested and approved for libido and seminal characteristics, were kept with the ewes at night in the pens. The same rams were used in all breeding seasons. In order to avoid the "male effect" when put with these breeding rams, ewes were kept with teaser rams 3 months prior to the start of the breeding season. The rams had their chests painted with colored grease to aid in the identification of the ewes in estrus. The color was changed every 15 days to facilitate reproduction monitoring and control, as described by Souza and Moraes (1998), and the females were observed twice a day for markings. Pregnancy diagnosis was performed four times at 15 days intervals, starting 30 days after the beginning of each breeding season. A transrectal ultrasound (100 Falco-Pie medical, Germany) equipped with a multi-frequency linear transducer (6.0 and 8.0 $\mathrm{MHz}$ ) was used with ewes in quadruped position, and all regions of the uterus were scanned to detect the presence of embryonic vesicles. Once pregnancies were diagnosed, ewes were placed in outdoor paddocks under the same feeding management. 
Table 1 The mean values of temperature (maximum $-T_{\max }$, minimum $-T_{\text {mín }}$, average $-T_{\text {average}}$ ), humidity, rainfall, and temperaturehumidity index $\left(\mathrm{THI}^{\mathrm{a}}\right.$, maximum- $-\mathrm{THI}_{\max }$ and average- $\left.-\mathrm{THI}_{\text {average }}\right)$ during the breeding seasons (wet, wet/dry transition, dry and dry/wet transition) and lambing seasons (meteorological data provided by the National Institute of Meteorology, 2nd District of Meteorology/PA, Brazil)

\begin{tabular}{|c|c|c|c|c|c|c|c|c|}
\hline Season & Month & $T_{\max }\left({ }^{\circ} \mathrm{C}\right)$ & $T_{\min }\left({ }^{\circ} \mathrm{C}\right)$ & $T_{\text {average }}\left({ }^{\circ} \mathrm{C}\right)$ & Humidity (\%) & Rainfall $\left(\mathrm{mm}^{3}\right)$ & $\mathrm{THI}_{\max }$ & $\mathrm{THI}_{\text {average }}$ \\
\hline \multirow[t]{4}{*}{ Breeding } & Jan/Feb & 32.3 & 22.8 & 28.4 & 77.5 & 173.3 & 86.1 & 80.0 \\
\hline & Apr/May & 32.2 & 22.7 & 27.0 & 80.5 & 334.5 & 86.5 & 78.1 \\
\hline & Jul/Aug & 32.8 & 21.6 & 26.7 & 82.5 & 110.3 & 87.8 & 77.9 \\
\hline & Oct/Nov & 33.5 & 20.7 & 29.4 & 69.0 & 35.2 & 86.4 & 80.3 \\
\hline \multirow[t]{4}{*}{ Lambing } & Jun/Jul & 32.4 & 21.5 & 26.7 & 81.0 & 154.3 & 86.9 & 77.7 \\
\hline & Sep/Oct & 33.5 & 20.7 & 28.2 & 74.0 & 51.9 & 87.3 & 79.2 \\
\hline & Dec/Jan & 31.5 & 21.4 & 28.0 & 75.5 & 198.0 & 84.5 & 79.1 \\
\hline & Mar/Apr & 32.5 & 24.0 & 26.6 & 80.0 & 287.5 & 86.9 & 77.4 \\
\hline
\end{tabular}

${ }^{\mathrm{a}} \mathrm{THI}=0.8 \times T+($ humidity $/ 100) \times(T-14.4)+46.4$, being $T=$ temperature, according to Thom $(1958)$

Ewes and lambs remained confined in pens $\left(2.0 \mathrm{~m}^{2} / \mathrm{ewe}\right)$ during the first 5 days postpartum, after which, the suckling was controlled with the lambs remaining in the pen while the ewes were grazing. At $12 \mathrm{PM}$, the ewes would return to the pens and remain with the lambs until $2 \mathrm{PM}$, when they were again separated and taken to pasture. At the end of the day, all animals would return to the pens where they remained until the morning. During the periods in which they were kept in the pens, ewes were fed ( $1 \%$ of live weight, adjusted monthly until weaning) cut Pennisetum purpureum as a supplement and, at the end of the day, animal feed. All lambs had access to creep-feeding with a commercial concentrate diet containing $17.9 \%$ of crude protein (Table 2) in the approximate quantity of $200 \mathrm{~g} / \mathrm{head} /$ day. Seventy-five days after birth, the suckling from 12 to $2 \mathrm{PM}$ was suppressed, and lambs were weaned at 90 days.

All ewes were weighed at the beginning and at the end of the breeding season and 1 week before and 1 week after parturition. Sequential weighing of the lambs was performed

Table 2 Composition and nutritional value of feed supplement provided to ewes and rams and lambs during experimental period

\begin{tabular}{lll}
\hline Ingredients (\%) & $\begin{array}{l}\text { Ewes and rams } \\
\text { kg MS }\end{array}$ & Lambs (creep-feeding) \\
\hline Corn (grain) & 15 & 30 \\
Wheat (bran) & 68 & 58 \\
Coco (bran) & 14.5 & - \\
Limestone & 2 & 1.5 \\
Salt & 0.5 & 0.5 \\
Soy (grain) & - & 10 \\
Calcium (Ca) & 0.858 & 0.671 \\
Phosphorus (P) & 0.807 & 0.727 \\
Crude protein & 18 & 17.9 \\
NDT & 73 & 76 \\
Total & 100 & 100 \\
\hline
\end{tabular}

(at birth, 15, 30, 60, and 90 days) to determine the lamb development and weight gain according to the time of birth. Reproductive efficiency was assessed by the following: (1) service rate $=$ number of served ewes $\times 100 /$ total of ewes in the breeding season at 15 (early), 30 (medium), and 45 (late) days; (2) pregnancy rate $=$ number of pregnant ewes $\times$ $100 /$ total of ewes in the breeding season; (3) lambing rate $=$ number of lambs lambed $\times 100 /$ total of ewes in the breeding season; (4) prolificacy rate $=$ number of lambs born $\times 100 /$ total of lambed ewes; (5) twinning rate $=$ number of multiple parturitions $\times 100 /$ total of parturitions; (6) pregnancy loss rate= number of ewes that aborted $\times 100 /$ total of pregnant ewes; (7) weaning rate $=$ number of lambs weaned $\times 100 /$ total of served females; and (8) lamb mortality rate $=$ number of dead lambs $\times 100 /$ total of lambs alive at 90 days post-partum. The reproductive efficiency index (number of lambs weaned/total of served females) and the productive efficiency index (kg of weaned lamb/kg of served ewe and KG of weaned lamb/kg of lambed ewe) were also calculated.

Data was analyzed by SAS ${ }^{\mathrm{TM}}$ software version 9.2 (SAS Institute, Cary, NC, USA, 2002-2012). The results on weight are expressed in means and standard deviation and were analyzed by ANOVA using the general linear model (GLM) of the $t$ Student test. The reproductive parameters assessed were compared using the chi-square test. Significance was considered at $5 \%$. In cases where the contingency of the expected frequency was less than five and the chi-square test ineffective, the Fisher exact test was used. Differences were considered significant when $\mathrm{P}<0.05$.

\section{Results}

Reproductive efficiency data are shown in Table 3. All ewes expressed estrus and were mated within the first 15 days of the breeding season, regardless of the period of the year. However, there was a higher percentage of ewes $(60.6 \%)$ that 


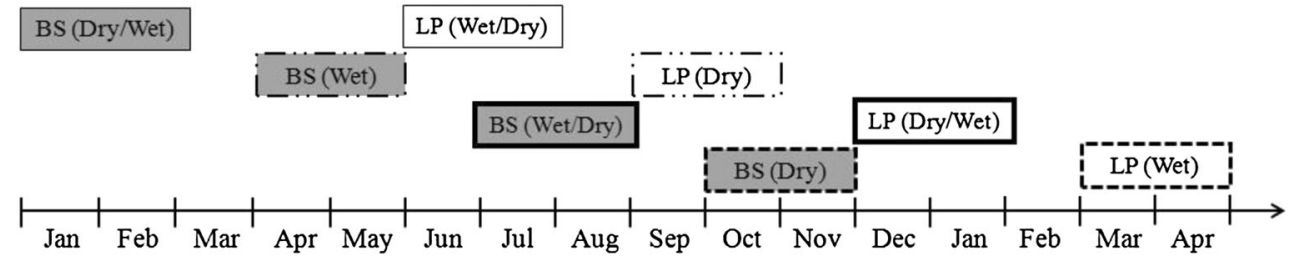

Fig. 1 Schematic representation of experimental design: four groups according to the time of the year of their breeding season (BS, i.e., mating period) and their respective periods of lambing (LP)

returned to estrus during the wet/dry transition period with higher service rates at $30(53.5 \%)$ and $45(7.1 \%)$ days of the breeding season when compared to the other climate periods $(P<0.05)$. The lower rates $(13.9 \%)$ of return to estrus at 30 days were observed for ewes breeding during the wet season $(P<0.05)$. There were no significant effects of breeding seasons on the remaining reproductive rates (pregnancy, lambing, prolificacy, twinning, pregnancy loss, weaning, and lamb mortality at 90 days).

Ewes' weight at the beginning and the end of the breeding season did not differ between the different periods of the year $(P>0.05$; Table 4); however, there was significant difference in the weights of the ewes at parturition. Ewes serviced in the wet/dry transition period (i.e., ewes lambed during the dry/wet transition period) weighted less $(40.7 \pm 2.5 \mathrm{~kg})$ before parturition than those of other groups $(P<0.05)$. Similarly, this group of ewes also weighted less $(38.6 \pm 1.6 \mathrm{~kg})$ after parturition than ewes served in dry/wet transition period and wet season $(P<0.05)$.

Results obtained for lamb weight prior to weaning are shown in Table 5. Lambs' weight at birth did not vary between groups $(P>0.05)$. However, there was difference in lamb development (i.e., lamb weight gain) between the different parturition periods. The weight at weaning (90 days old) was higher $(15.6 \pm 2.1 \mathrm{Kg})$ in lambs born during the wet season $(P<0.05)$.
The reproductive efficiency index was lower $(0.66)$ when the breeding season was conducted during the dry/wet transition period than during the others climate periods $(P<0.05$; Table 6$)$. The productive rates were significantly higher $(0.29$ and 0.33 for $\mathrm{kg}$ of weaned lamb/kg of served and lambed ewes, respectively; $P<0.05$ ) in the group of ewes served in the dry season (i.e., lambs born during the wet season).

\section{Discussion}

Ewes from equatorial regions are not significantly influenced by seasonality (i.e., ewes cycle all year round), which occurs due to slight variations in day length throughout the year (Oliveira et al. 2013b). As expected, in this study was not observed interfere of the time of the year in which the breeding season on estrus expression of ewes. The higher service rates at 15 days of breeding season was more desire because it enhances the probability to reduce the lambing interval (Oliveira et al. 2013a).

As animals reared in tropical regions are unaffected by photoperiod, other factors such as climate (e.g., heat stress), nutrition, and lactation/suckling become considerable effect on the reproductive performance of flocks. Thus, the regional climate, characterized by high temperatures and humidity, had important influence on the animals. Our experimental data
Table 3 Reproductive rates (\%) according to the breeding season periods (dry/wet, wet, wet/dry, and dry) of Santa Inês ewes in humid tropical climate

\begin{tabular}{llllll}
\hline & \multicolumn{2}{l}{ Breeding season } & & \\
\cline { 2 - 5 } & Dry/wet & Wet & Wet/dry & Dry & \multirow{2}{*}{$P$} \\
\hline Service rate at 15 days & $100.0(30 / 30)$ & $100.0(43 / 43)$ & $100.0(28 / 28)$ & $100.0(47 / 47)$ & 1.0 \\
Service rate at 30 days & $30.0 \mathrm{~b}(9 / 30)$ & $13.9 \mathrm{c}(6 / 43)$ & $53.5 \mathrm{a}(15 / 28)$ & $27.6 \mathrm{~b}(13 / 47)$ & 0.005 \\
Service rate at 45 days & $0.0 \mathrm{~b}(0 / 30)$ & $0.0 \mathrm{~b}(0 / 43)$ & $7.1 \mathrm{a}(2 / 28)$ & $0.0 \mathrm{~b}(0 / 47)$ & 0.033 \\
Pregnancy rate & $86.6(26 / 30)$ & $88.3(38 / 43)$ & $89.2(25 / 28)$ & $91.4(43 / 47)$ & 0.123 \\
Lambing rate & $70.0(21 / 30)$ & $79.0(34 / 43)$ & $82.1(23 / 28)$ & $87.2(41 / 47)$ & 0.314 \\
Prolificacy rate & $104.0(22 / 21)$ & $105.0(45 / 43)$ & $100.0(28 / 28)$ & $102.0(48 / 47)$ & 0.336 \\
Twinning rate & $3.3(1 / 30)$ & $4.6(2 / 43)$ & $0.0(0 / 28)$ & $2.1(1 / 47)$ & 0.682 \\
Pregnancy loss rate & $13.3(4 / 30)$ & $9.3(4 / 43)$ & $7.1(2 / 28)$ & $2.1(1 / 47)$ & 0.300 \\
Weaning rate & $66.6(20 / 30)$ & $74.4(32 / 43)$ & $75.0(21 / 28)$ & $76.6(36 / 47)$ & 0.800 \\
Lamb mortality rate at 90 days & $9.1(2 / 22)$ & $8.9(4 / 45)$ & $7.1(2 / 28)$ & $14.8(7 / 48)$ & 0.599 \\
\hline
\end{tabular}

Values with different lowercase letters in a row differs significantly at $P<0.05$ 
Table 4 Summary of the weight performance (mean \pm SD) of Santa Inês ewes bred at different periods (dry/wet, wet, wet/dry, and dry) in humid tropical climate

\begin{tabular}{|c|c|c|c|c|c|}
\hline & Dry/wet & Wet & Wet/dry & Dry & $P$ value \\
\hline Ewe weight at the beginning of breeding season $(\mathrm{kg})$ & $40.0 \pm 5.2$ & $40.7 \pm 6.4$ & $39.5 \pm 3.0$ & $39.6 \pm 4.0$ & 0.675 \\
\hline Ewe weight at the end of breeding season $(\mathrm{kg})$ & $40.0 \pm 5.2$ & $40.8 \pm 6.5$ & $40.5 \pm 2.8$ & $41.7 \pm 4.1$ & 0.478 \\
\hline Ewe weight before parturition (kg) & $43.7 \pm 4.0 \mathrm{a}$ & $44.6 \pm 6.2 \mathrm{a}$ & $40.7 \pm 2.5 b$ & $43.2 \pm 4.2 \mathrm{a}$ & 0.008 \\
\hline Ewe weight after parturition (kg) & $40.8 \pm 2.6 \mathrm{ab}$ & $42.1 \pm 5.1 \mathrm{a}$ & $38.6 \pm 1.6 \mathrm{c}$ & $40.4 \pm 8.7 \mathrm{bc}$ & 0.010 \\
\hline
\end{tabular}

Values with different lowercase letters in a row differs significantly at $P<0.050$

shows that ewes were subjected to severe environmental conditions, which probably induce great thermal distress of the animals throughout all the study (THImean and THImax classified as critical, dangerous, or emergency levels of discomfort, according to Hahn 1985). However, the environmental condition had no direct effect on reproductive parameters studied in this experiment. Nevertheless, it is essential to consider the need to implement management practices that favor the comfort of the animals (i.e., areas providing shade and shelter from rain in the pasture, access to abundant water, etc.) (Oliveira et al. 2013a).

Possible variations observed between the periods studied may be due to the availability and quality of the feed, as well as the adaptation of animals to the management conditions. It is known that reproduction performance can be influenced by rainfall, which in turn influences pasture quality and animal nutrition (Lima 1996). Furthermore, Martins et al. (2008) have reported that in native sheep breeds, the greatest return to estrus rates (44.4\%) were observed in April and May (dry season) in Mato Grosso do Sul State of Brazil (latitude approximately $20^{\circ} \mathrm{S}$ ). Thus, the lowest return to service rates observed in ewes serviced during the wet season could be due to the greater quality of the pastures available at the time. The period in which the breeding seasons took place did not interfere with the remaining reproduction rates, and uniformity could be observed throughout the year. The percentage of pregnancy, parturition, prolificacy, and twin pregnancy rates were satisfactory considering the reproductive and productive efficiency of sheep flocks. Similar results have been previously reported for the various regions of Brazil (North: Moura et al. 2014; Northeast: Albuquerque et al. 2007; Southeast: Morais 2006 and Figueiredo et al. 2007). It is important to point out that the prolificacy of Santa Inês ewes can be greater than those observed in this study, as reported by Figueiredo et al. (2007; 1.94). Prolificacy is a genetic trait (Fogarty 2009); however, the degree to which it can be expressed is influenced by environmental factors, in particular those related to nutrition (Abecia et al. 2006, Fitz-Rodrígueza et al. 2009). The similarity of the results obtained during the various breeding seasons suggest that the environment was not a limiting factor for prolificacy and that the data obtained was the result of the animals genetics.

The average weight of the ewes recorded in this study is in keeping with the standard weights for Santa Inês ewes. Although the nutrition of the animals consisted mainly of pastures, which can have its quality influenced by the climate, the differences between the periods did not alter the weight of the ewes at the beginning or at the end of the breeding season. However, the variation in weight close to parturition seems to be associated with the quality of the feed provided on the last third of gestation, with the lowest weights before and after parturition having been observed in ewes that lambed in the transition period from the dry to wet season (i.e., ewes that had the last third of the gestation period during the dry season). It is known that females that have lambed underweight have longer postpartum anoestrus and higher lambing interval, therefore impaired reproductive efficiency. In this way, Knights et al. (2012) showed that ewes, and in particular aseasonal breeds, when provided with an optimum nutritional and a favorable photoperiodic environment do not require

Table 5 Summary of the weight performance (mean \pm SD) of lambs according to the parturition period (wet/dry, dry, dry/wet, and wet) in humid tropical climate

\begin{tabular}{|c|c|c|c|c|c|}
\hline & Wet/dry & Dry & Dry/wet & Wet & $P$ value \\
\hline Lamb weight at birth $(\mathrm{kg})$ & $3.1 \pm 0.5$ & $3.2 \pm 0.5$ & $3.0 \pm 0.3$ & $3.1 \pm 0.5$ & 0.405 \\
\hline Lamb weight at 15 days $(\mathrm{kg})$ & $5.9 \pm 0.9 \mathrm{a}$ & $4.8 \pm 0.9 b$ & $4.6 \pm 0.5 b$ & $4.5 \pm 0.8 b$ & 0.0001 \\
\hline Lamb weight at 30 days $(\mathrm{kg})$ & $9.4 \pm 2.8 \mathrm{a}$ & $8.4 \pm 2.0 \mathrm{~b}$ & $5.9 \pm 0.7 \mathrm{~d}$ & $7.2 \pm 0.9 \mathrm{c}$ & 0.0001 \\
\hline Lamb weight at 60 days $(\mathrm{kg})$ & $11.2 \pm 2.8 \mathrm{ab}$ & $11.9 \pm 2.8 \mathrm{a}$ & $7.8 \pm 1.0 \mathrm{c}$ & $10.9 \pm 1.6 b$ & 0.0001 \\
\hline Lamb weight at 90 days $(\mathrm{kg})$ & $14.0 \pm 2.3 \mathrm{~b}$ & $14.2 \pm 2.7 \mathrm{~b}$ & $14.6 \pm 2.2 \mathrm{ab}$ & $15.6 \pm 2.1 \mathrm{a}$ & 0.044 \\
\hline
\end{tabular}

Values with different lowercase letters in a row differs significantly at $P<0.050$ 
Table 6 Summary of productive performance results according to the breeding season periods (dry/ wet, wet, wet/dry, and dry) of Santa Inês ewes in humid tropical climate

\begin{tabular}{lccccc}
\hline & Dry/wet & Wet & Wet/dry & Dry & $P$ value \\
\hline Reproductive efficiency & $0.66 \mathrm{~b}$ & $0.74 \mathrm{a}$ & $0.75 \mathrm{a}$ & $0.73 \mathrm{a}$ & 0.044 \\
Kilogram of weaned lamb/kilogram of served ewe & $0.18 \mathrm{~d}$ & $0.24 \mathrm{c}$ & $0.27 \mathrm{~b}$ & $0.29 \mathrm{a}$ & 0.030 \\
Kilogram of weaned lamb/kilogram of lambed ewe & $0.24 \mathrm{~d}$ & $0.29 \mathrm{c}$ & $0.31 \mathrm{~b}$ & $0.33 \mathrm{a}$ & 0.019 \\
\hline
\end{tabular}

Values with different lowercase letters in a row differs significantly at $P<0.050$ weaning to resume cyclicity and show high levels of fertility when bred after day 70 postpartum.

In sheep and goat flocks, it is relatively common to see differences for lamb mortality up to weaning or for weaning rates between periods of birth throughout the year, especially due to the climatic influences. In the present study, this variation was not observed; however, Moura et al. (2014) reported greater mortality in lambs born during the dry season, suggesting a correlation between the low milk production and the high maternal rejection observed during this period. On the other hand, higher mortality rate in lambs born during the wet season commonly relates the difficulty of homeothermy due to intense rainfall, and lighter lambs are more susceptible to hypothermia than heavy lambs (Clarke et al. 1997). Therefore, we believe that in this study, the animals were subjected to proper management, which allowed the lamb birth weight in agreement for the Santa Ines breed standard (Moura et al. 2014, $3.1 \mathrm{~kg}$; Oliveira et al. 2013a, $3.65 \mathrm{~kg}$ ) and appropriate weights of ewes at parturition did not decrease milk production and as a consequence avoided variation between periods of the year.

The results on lamb birth weight show that there was a significant difference $(P=0.02)$ only in relation to sex $(3.24$ \pm 0.49 and $3.07 \pm 0.33$ for males and females, respectively; data not provided). Similar results have been previously reported by Silva et al. (1995), with male lambs weighing in average $6.5 \%$ more than females lambs. It is important to point out the difference observed in lamb weight at weaning between the different seasons with greater weight being observed in lambs born during the wet season. These results suggest, once again, the influence of climate and nutrition on flock production and reproduction. The variation in lamb weight at weaning does not limit the use of four breeding seasons in a year, as performed in the present study; however, it is important to adopt husbandry practices such as nutritional supplementation of ewes through flushing (Fthenakisa et al. 2012) and of lambs through creep-feeding (Karim et al., 2001) that can overcome feed variations throughout the year.

Reproductive efficiency rate lower when the breeding season took place during the transition period from the dry to the wet season probably is due to pregnancy losses and lamb death before weaning, and although no significant difference between the different periods of the year was observed for these parameters, it is important to avoid such reproductive failures. The lower quality of pasture during dry/wet transition period could lead to a decreasing in reproductive efficiency rates. Knights et al. (2012) and Hatcher et al. (2010) observed significantly higher mortalities in lambs that were lighter at weaning. Thus, the understanding of these seasonal variations is of uttermost importance for the selection of strategies and methods aimed at improving reproductive efficiency.

Productive performance $(\mathrm{kg}$ weaned lamb/ $\mathrm{kg}$ served or lambed ewes) greater for ewes served during the dry season and that lambed during the wet season is related to the record of greater weight at weaning for lambs belonging to this group of animals. The values of productive performance obtained during this period are similar to those observed for Corriedale, Hampshire-Down, Ile de France, and Suffolk flocks (Ribeiro et al. 2008). These results show the adaptability and productive potential of Santa Inês sheep raised in the Amazon region. The productive and reproductive performance of Santa Inês ewes under the tropical climate of the Amazon region presented good results in all seasons. Thus, the data generated is of great importance to guide standards for livestock raised in similar conditions as well as encourage husbandry practices aiming to increase efficiency.

Finally, is important to highlight that the Amazon region has similar climatic conditions between years. Nevertheless, we consider the need to expand research on the production of lambs under severe environmental conditions to investigate in more detail its effects on physiological aspects. As a consequence, adjust strategies aimed to optimize the productive and reproductive efficiency of animals.

In conclusion, the reproductive performance of Santa Inês ewes was not significantly influenced by the period in which the breeding seasons took place, suggesting the possibility of having four breeding seasons throughout the year in the Amazon region. Nevertheless, there were variations between periods in the rates of return to estrus, weight of ewes close to parturition, and lamb weight at weaning, proposing that climate changes can affect reproductive rates as it does with productive rates.

Acknowledgments We would like to thank CNPq/CAPES (Ação Transversal no. 06/2011 Casadinho/Procad), CNPq (Postdoctoral scholarship) and the State of Sao Paulo Research Foundation (FAPESP, Brazil) for their support of this study.

Conflict of interest The authors declare that they have no competing interest. 


\section{References}

Abecia, J.A., Sosa, C., Forcada, F., Meikle, A. 2006. The effect of undernutrition on the establishment of pregnancy in the ewe. Reproduction Nutrition and Development, 46, 367-378.

Albuquerque, F.H.M.A.R., Martins, G.A., Rogério, M.C.P., Memória, H.Q., Sousa, R.T.; Nascimento Júnior, P.S., Gomes, G.L., Farias, D.C., Araújo, J.F., 2007. Índices zootécnicos de rebanho ovino no estado do Ceará. In: Proceeding of 1st Zootec, 2007, 1-4 (expanded abstract).

Clarke, L., Bryant, M.J., Lomax, M.A., Symonds, M.E., 1997. Maternal manipulation of brown adipose tissue and liver development in the ovine fetus during late gestation. British. Journal of Nutrition, 77, 871-883.

Costa, E.P.S., Takeda, F.R.P.C., Lima, R.S., 2010. Avaliação da Adaptabilidade de Ovinos Santa Inês ao Clima Amazônico. Revista Electrônica de Veterinária, 11, 1-8.

Façanha, D.A.E., Chaves, D.F., Morais, J.G., Vasconcelos, A.M., Costa, W.P., Guilhermino, M.M., 2013. Tendências metodológicas para avaliação da adaptabilidade ao ambiente tropical. Revista brasileira de saúde e produção animal, 14 (1), 91-103.

Figueiredo, C.L., Balieiro, J.C.C., Mattos, E.C., Balieiro, C.C., Eler, J.P., Ferraz, J.B.S., 2007. Estimativas de parâmetros genéticos para fertilidade ao parto e número de cordeiros nascidos ao parto em ovinos da raça Santa Inês. In: Proceeding of the 44th Annual Meeting of SBZ, 2007, 1-3 (expanded abstract).

Fitz-Rodrígueza, G., De Santiago-Miramontesa, M.A., Scaramuzzib, R.J., Malpaux, B., Delgadillo, J.A., 2009. Nutritional supplementation improves ovulation and pregnancy rates in female goats managed under natural grazing conditions and exposed to the male effect. Animal Reproduction Science, 116, 85-94.

Fogarty, N.M., 2009. A review of the effects of the Booroola gene (FecB) on sheep production. Small Ruminant Research, 85, 75-84.

Fthenakisa, G.C., Arsenosb, G., Brozosb, C., Fragkou, I.A., Giadinis, N.D., Giannenas, I., Mavrogianni, V.S., Papadopoulos, E., Valasi, I., 2012. Health management of ewes during pregnancy. Animal Reproduction Science, 130, 198-212.

Gunn, R.G., Doney, J.M., Smith, W.F., Sim, D.A., 1984. Effects of age and its relationship with body size and reproductive performance in Scottish black face ewes. Animal Production, 43, 279-283.

Hahn, G.L., 1985. Management and housing of farm animals in hot environments. In: YOUSEF, M.K. Stress physiology in livestock, v. 2 (Ed.). Boca Raton: CRC Press, 151-174.

Hatcher, S., Eppleston, J., Thornberry, K.J., Watt, B., 2010. High Merino weaner survival rates are a function of weaning weight and positive post-weaning growth rates. Animal Production Science 50, 465472.

IBGE - Instituto Brasileiro De Geografia E Estatística. Pesquisa Pecuária Municipal, 2011. ftp://ftp.ibge.gov.br/Producao_Pecuaria/ Producao_da_Pecuaria_Municipal/2011/ppm2011.pdf Accessed 20 July 2013.

Karim, S.A., Santra, A., Sharma, V.K., 2001. Pre-weaning growth response of lambs fed creep mixtures with varying levels of energy and protein. Small Ruminant Research, 39, 137-144.
Knights, M., Siew, N., Ramgattie, R., Singh-Knights, D., Bourne, G., 2012. Effect of time of weaning on the reproductive performance of Barbados Blackbelly ewes and lamb growth reared in the tropics. Small Ruminant Research, 103, 205-210.

Lima, F.R.G. 1996.Performance reprodutiva de cabras nativas criadas no sertão do Ceará submetidas a diferentes tratamentos de sincronização de estro (unpublished Masters dissertation, State University of Ceará).

Martins, C.F., Vargas, F.M., Pinto, G.S., 2008. Aspectos reprodutivos da ovelha nativa sul mato-grossense. In: Proceeding of the 45th Annual Meeting of SBZ, 2008, 1-3 (expanded abstract).

Morais, O. R., 2006. Valores econômicos para características de produção de ovinos Santa Inês. (unpublished PhD Thesis, Federal University of Minas Gerais).

Moura, A.C.M.; Teixeira, P.P.M.; Coutinho, L.N.; Paz, C.C.; Santos, V.J.C.; Soares, F.N.; Oliveira, M.E.F.; Vicente, W.R.R.; Araújo, A.A.; Rodrigues, L.F.S., 2014. Reproductive performance of Santa Inês ewes during dry and rainy seasons in eastern Amazon. Animal Reproduction, 11 (1), 44-48.

Neiva, J.N.M., Teixeira, M., Turco, S.H.N., Oliveira, S.M.P., Moura, A.A.A.N., 2004. Efeito do Estresse Climático sobre os Parâmetros Produtivos e Fisiológicos de Ovinos Santa Inês Mantidos em Confinamento na Região Litorânea do Nordeste do Brasil. Revista Brasileira de Zootecnia, 33 (3), 668-678.

Oliveira, M.E.F., Cordeiro, M.F., Feliciano, M.A.R., Oliveira, L.G., 2013b. Fisiologia do ciclo estral. In: Oliveira, M.E.F., Teixeira, P.P.M., Vicente, W.R.R. (Eds.). Biotécnicas reprodutivas em ovinos e caprinos. (Editora MedVet, São Paulo), 17-24.

Oliveira, M.E.F., Sousa, H.L.L., Moura, A.C.B., Vicente, W.R.R., Rodrigues, L.F.S., Araújo, A.A., 2013a. The effects of parturition season and suckling mode on the puerperium of Santa Ines ewes and on the weight gain of lambs. Arquivo Brasileiro de Medicina Veterinária e Zootecnia, 65 (3), 857-864.

Ribeiro, E.L.A., Mizubuti, I.Y., Silva, L.D.F., Rocha, M.A., Mori, R.M., 2008. Desempenho produtivo de ovelhas submetidas a acasalamentos no verão ou no outono no Norte do Paraná. Ciências Agrárias, 29 (1), 229-236.

Silva, F.L.R., Figueiredo, E.A.P., Barbieri, M.E., Simplicio, A.A., 1995. Efeito de ambiente e de reprodutor sobre as características de crescimento e de reprodução em ovinos Santa Inês, no estado do Ceará. Revista da Sociedade Brasileira de Zootecnia, 24 (4), 559569.

Silva, S.V., Soares, A.T., Batista, A.M., Almeida, F.C., Guerra, M.M.P., 2011. Interferência da condição climática na integridade de espermatozoides ovinos submetidos à criopreservação. Arquivo Brasileiro de Medicina Veterinária e Zootecnia, 63 (6), 1309-1314.

Simplício, A.A., 2008. Estratégias de manejo reprodutivo como ferramenta para prolongar o período de oferta de carnes caprina e ovina no Brasil. Tecnologia e Ciência Agropecuária, 2, 29-39.

Souza, C.J., Moraes, J.C.F., 1998. Manual de sincronização de cios em bovinos e ovinos. Bagé: Embrapa Pecuária Sul, Comunicado Técnico 13, 1-75.

Thom, E.C., 1958. Cooling degree "day air conditioning, heating, and ventilating. In: Transactions of the American Society Heating Refrigeration Air-Conditionning Engrs, 55, 65-72. 